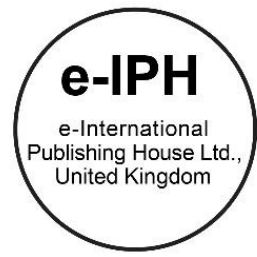

\title{
Discord in the Family Environment: Reviewing incidences of fratricide and sororicide in Malaysia
}

\author{
Rugayah Hashim ${ }^{1 *}$, Hashim Ahmad ${ }^{1}$, Nursyahida Zulkifli ${ }^{2}$, Nur Liyana Zainal Bahrin ${ }^{3}$ \\ ${ }^{1}$ Faculty of Administrative Science \& Policy Studies, Universiti Teknologi MARA, Shah Alam 40450, Selangor, Malaysia \\ ${ }^{2}$ Faculty of Administrative Science \& Policy Studies, Universiti Teknologi MARA, Raub, Pahang, Malaysia \\ ${ }^{3}$ Faculty of Pharmacy, University Teknologi MARA, Puncak Alam, Selangor, Malaysia
}

\begin{abstract}
Family discords or quarrels are considered normal and ordinary. However, the level and intensity of the discords and disputes have led to incidences of fratricide and sororicide. In the case of fratricide (the killing of one's brother) and sororicide (the killing of one's sister), the escalating number of incidences as reported in the media requires proper intervention by the relevant parties. The aim of this paper is to review published articles on family discords and violence, particularly on incidences of fratricide and sororicide. The findings and implications of the findings will be discussed in this review paper.
\end{abstract}

Keywords: fratricide; sororicide; discord; family environment

ISSN: 2398-4287@ 2017. The Authors. Published for AMER ABRA by e-International Publishing House, Ltd., UK. This is an open access article under the CC BYNC-ND license (http://creativecommons.org/licenses/by-nc-nd/4.0/). Peer-review under responsibility of AMER (Association of Malaysian Environment-Behaviour Researchers), ABRA (Association of Behavioural Researchers on Asians) and cE-Bs (Centre for Environment-Behaviour Studies), Faculty of Architecture, Planning \& Surveying, Universiti Teknologi MARA, Malaysia.

\subsection{Introduction}

Socio-economic growth at the macro level has a strong, positive relationship to a harmonious family environment at the micro level. In tandem with population increment, incidences on the erosion of community integration have been significant, particularly within the nuclear, home environment. Family feuds are considered common, and the regularity of the domestic interchanges depends on family harmony (Kiong, 2005). Nevertheless, family discords or quarrels are part of the human lifecycle and are considered normal and ordinary (Wallace, 2015). However, the level and intensity of the disputes have led to incidences of fratricide and sororicide. In the case of fratricide (the killing of one's brother) and sororicide (the killing of one's sister), the escalating number of incidences as reported in the media requires proper intervention by the relevant parties (Bourget \& Gagné, 2006). Therefore, the aim of this paper is to provide evidence and insights through a rigorous review of the literature on the incidences of fratricide and sororicide through sibling rivalries in Malaysia. Also, this paper deserves responses to these questions: How serious is sibling violence in Malaysia and, what are the factors that provoked sibling violence?

On another note, it is important to clarify that fratricide, and sororicide is considered sibling violence or homicide (aka, siblicide) (Gebo, 2002). Therefore, these interchangeable terms will be regularly used throughout this paper.

\subsection{Background}

Much like other families throughout the world, happiness and harmony are two important elements in defining a community and society's well-being. However, in conservative Asian families, aspects of domestic violence, particularly among siblings have remained largely overlooked (Hashim \& Ahmad, 2016; Kiselica \& Morrill-Richards, 2007). This is because family disputes are considered private matters and should remain in the closet. The time has come for such issues to be heard and assistance provided

\footnotetext{
* Corresponding author. Tel.: +603-55444158

E-mail address: guy73106@yahoo.com
}

ISSN: 2398-4287@ 2017. The Authors. Published for AMER ABRA by e-International Publishing House, Ltd., UK. This is an open access article under the CC BYNC-ND license (http://creativecommons.org/licenses/by-nc-nd/4.0/). Peer-review under responsibility of AMER (Association of Malaysian Environment-Behaviour Researchers), $A B R A$ (Association of Behavioural Researchers on Asians) and cE-Bs (Centre for Environment-Behaviour Studies), Faculty of Architecture, Planning \& Surveying, Universiti Teknologi MARA, Malaysia.

DOI: http://dx.doi.org/10.21834/e-bpj.v2i5.680 
to the victims. The perpetrators too should be taken to task with special acts and laws as well as special programs that are specifically designed to prevent family violence (Card \& Dahl, 2009; Eriksen \& Jensen, 2006).

The outcome of this investigation is important to the Ministry of Women, Family and Community Development in curtailing the escalating incidences of family violence leading to discord. Having an inclusive and civil society are important indicators of significant socio-economic growth, which is in line with the Prime Minister's recent tabling of Budget 2017, and the government's national blue ocean strategy (NBOS) aimed at caring for the wellbeing of Malaysia's women, youth, and families.

\subsection{Literature Review - Fratricide and Sororicide Cases}

This section provides an overview of the literature reviewed on the incidences of fratricide and sororicide (aka siblicide) throughout the world before focusing on similar cases leading to family discords occurring in Malaysia.

No matter which part of the world, family violence leading to extreme brutality such as murder cases are front-page news in local tabloids. Bullying cases have had their share of "viral"-ness in social media platforms. The extent of brutalities is no longer limited to oral abuse but physical harm (DeKeseredy \& Ellis, 1997; R. Khan \& Cooke, 2013). This phenomenon is more widespread and deserves special investigations (D'Amico and Minenna (2013). These cases are rapidly increasing due to many factors such as mental disorder, argument or fighting, drunk and revenge (Eriksen \& Jensen, 2009). One perception study of university students towards sibling violence evidenced mistreatments among and between siblings (Relva, Alarcão, \& Fernandes, 2014). Another study found that brothers have significantly higher levels of sibling violence than sisters, or brother towards sister and vice versa (Huffman, Jill Kiecolt, \& Edwards, 2005). The study also found that discord or trigger effect for family violence are associated with negative parent-child interactions which inherently leads to problems in siblings' relationships with each other.

Anyhow, sibling violence includes physical, emotional or sexual abuse of one sibling to another. In extending the definition of physical abuse, Boyse (2012) described it as ranging "from more mild forms of aggression between siblings, such as pushing and shoving, to very violent behavior such as using weapons", As observed by Boyse (2012), some parents usually ignore and don't see the abuse as a problem as they, and society expect fights and aggression among siblings. Only when things get out of hand will parents take action. By that time, it would be too late if there is a fatality.

Boyse (2012) also noted that sibling abuse does have signs for parents to detect, which are:

- One child always avoids their sibling

- A child has changed in behavior, sleep patterns, eating habits, or has nightmares

- A child acts out abuse in play

- A child acts out sexually in inappropriate ways

- The children's roles are rigid: one child is always the aggressor, the other, the victim

- The roughness or violence between siblings is increasing over time

In an aggression research like this, the measurement of violence is a major challenge because of the heterogeneous nature of the violent behavior (R. Khan \& Cooke, 2013). Khan and Cooke's (2013) findings showed the uniqueness in the offender-victim situation including age, severity and weapon use. This age evidence confirmed Sulloway's findings (as reported in (Marleau, 2005)) that older siblings were more like to be fratricidal than younger ones. In fact, most of the aggressors in Marleau's investigation were under the age of 18 years which supports the Adlerian theory of dethronement.

Another side of family violence is the birth order (Chang \& Luo, 2015), whether first born and so on. Again Marleau's study showed that first-borns were more often the aggressor than the victim. The same result is corroborated by Lawson and Mace (2010). Nevertheless, the initial exposure to violence usually starts at home, perhaps between parents. This is where the older child would witness the aggression and would internalize this behavior thinking that violence is permitted among family members (Lichter \& McCloskey, 2004; Tucker \& Finkelhor, 2015; van Beekum, 2009). As indicated by Karlsson, Temple, Weston, and Le (2016), "witnessing mother-to-father" violence and acceptance of female-perpetrated violence were the most consistent predictors of psychological teen dating violence."

In connecting the literature with the real-life incidents of siblicide for Malaysia, Table 1 shows some of the latest altercations that have resulted in fatalities. As reported in the Borneo Post, a man was killed by his elder brother with a homemade gun. The reason for the siblicide was because the younger brother was angry at his elder brother for asking his son to go to the store to buy him a packet of instant noodles. After a heated argument between the two, uncontrollable rage resulted in the death of one sibling. Squabbles between brothers usually started with something trivial as shown in the second case, over the television remote device. On the other hand, the third case involved different-gender sibling relationship where the sister was killed for nagging the younger brother. Nicholas (2014) reported that a heated argument between a sister and her younger brother ended in her death. Again, uncontrollable rage was the catalyst for the killing.

Another local incident on fratricide occurred in Rawang where an argument between two brothers led to the death of another. The sibling rivalry was a long-standing family issue, and substance abuse was also the catalyst to the murder (Hariz, 2016). Another fratricide case was reported by Nambiar (2016) in Free Malaysia Today where the suspect, a 32-year old man, purchased a firearm illegally on the black market and killed four members of his family consisting of his elder brother, his mother and her boyfriend, a younger brother and his two-year-old nephew. The alibi for the premeditated murder were money issues and substance abuse. Nevertheless, the rest of the cases in Table 1 showcased other fratricide and sororicide incidents in Malaysia and elsewhere. As a 
summary, siblicide is a very serious offense, and society should not ignore the mental health of family members. As noted by Khan and Cooke (2013), inter-sibling violence is now increasingly recognized as a pervasive form of family violence. Neighbors and community leaders should interfere if there are noticeable changes in the family next-door before it is too late. Lastly, the repercussions will be long-term family relationship difficulties or discord that would extend into adulthood. Moreover, Boyse (2012) pointed out that the abuser is also at psychological risk in the long run with behavioral and mental health problems.

Table 1. Fratricide, Sororicide and Sibling Rivalry Incidents

\begin{tabular}{|c|c|c|}
\hline Incident & Source & Comments \\
\hline Man kills younger brother over Maggi mee & $\begin{array}{l}\text { BorneoPost Online, } \\
\text { May } 31,2016\end{array}$ & Fratricide \\
\hline Squabble over TV turns deadly for two siblings & $\begin{array}{l}\text { BorneoPost Online, } \\
\text { July } 4,2016\end{array}$ & Fratricide \\
\hline Sister found dead after scolding brother & $\begin{array}{l}\text { The Star, October } \\
28,2014\end{array}$ & Siblicide \\
\hline Brothers' quarrel end in murder & $\begin{array}{l}\text { NST, March 23, } \\
2016\end{array}$ & Fratricide \\
\hline Man wanted for killing 4 in a family shot dead & $\begin{array}{l}\text { Free Malaysia } \\
\text { Today, July 24, } 2016\end{array}$ & Fratricide \\
\hline Older brother bleeds to death during fight & $\begin{array}{l}\text { The Star, October } \\
31,2016\end{array}$ & Fratricide \\
\hline When the siblings quarrel & $\begin{array}{l}\text { The Star, October } 6 \text {, } \\
2016\end{array}$ & Sibling rivalry \\
\hline $\begin{array}{l}\text { 18-year old wanted for killing sister, stabbing brother } \\
\text { in Maryland }\end{array}$ & $\begin{array}{l}\text { NBC4, September } \\
13,2016\end{array}$ & Siblicide \\
\hline $\begin{array}{l}\text { Teen covered in siblings' blood arrested in } \\
\text { 'gruesome' fatal stabbing of his 3-year old brother }\end{array}$ & $\begin{array}{l}\text { The Washington } \\
\text { Post, August 9, } 2016\end{array}$ & Fratricide \\
\hline $\begin{array}{l}\text { Man kills brother in argument over cheeseburger, } \\
\text { police say }\end{array}$ & CNN, May 9, 2016 & Fratricide \\
\hline Boy, 12 , stabbed baby brother to death & $\begin{array}{l}\text { Mail Online, } \\
\text { November 23, } 2016\end{array}$ & Fratricide \\
\hline $\begin{array}{l}\text { 6-year old beats infant sister to death while US mom } \\
\text { shops }\end{array}$ & $\begin{array}{l}\text { BorneoPost Online, } \\
\text { August } 14,2016\end{array}$ & Sororicide \\
\hline Married couple charged with murder of little sister & $\begin{array}{l}\text { The Sun Daily, } \\
\text { September 8, } 2016\end{array}$ & Sororicide \\
\hline $\begin{array}{l}\text { Three siblings assault brother over inheritance in } \\
\text { Besut }\end{array}$ & $\begin{array}{l}\text { The Sun Daily, May } \\
15,2016\end{array}$ & Sibling assault \\
\hline $\begin{array}{l}\text { Unemployed man sentenced to } 27 \text { months' jail for } \\
\text { mischief, hurting younger siblings }\end{array}$ & $\begin{array}{l}\text { The Sun Daily, } \\
\text { August 17, } 2016\end{array}$ & Sibling assault \\
\hline
\end{tabular}

\subsection{Methodology}

The methodology employed for this concept paper involves systematic reviews and meta-analyses on sibling rivalry. Through a clearly formulated research objective, the identification of relevant studies was undertaken. Literature searches were done using the online databases subscribed by the library, Universiti Teknologi MARA as well as via Scholar Google. Primarily, the Scopus and Web of Science databases formed the bulk of the searches. As a result, the systematic and explicit approaches allowed for evidence summary (K. S. Khan, Kunz, Kleijnen, \& Antes, 2003).

In writing this concept paper, elements of rigor for reliability and validity of the findings are crucial. The evidence are required for the construction of the conceptual and theoretical frameworks. Nonetheless, within the spectra of sibling rivalry and family violence, the review of literature allows for the contribution to the breadth of knowledge. In fact, for the area of sociology and behavioral studies, literature reviews are also in great demand like most other scientific fields (Pautasso, 2013).

Also, the number of articles reviewed must be adequate to ensure that the content was rigorously pondered. However, from the 30 articles reviewed, only the relevant ones are scrutinized. Within the behavioral theory, the analyses will include patterns, incidences, and trends as well as distributions.

\subsection{Findings}

The findings revealed that most of the sibling violence cases and killings involved the male sibling or fratricide (see Table 2). The average of incidences of fratricide is between 18 to 40 years. The occurrence of sororicide, on the other hand, is scarce as shown in Table 1. The main catalyst for both fratricide and sororicide is jealousy. Other catalysts include mental health, substance abuse (drugs and alcohol) and uncontrollable rage (psychological challenges). The discussion on these findings will be done in the next section.

Table 2. Articles reviewed on Fratricide, Sororicide or Siblicides

\begin{tabular}{|l|l|l|}
\hline \multicolumn{1}{|c|}{ Article title } & \multicolumn{1}{|c|}{ Source } & \multicolumn{1}{c|}{ Findings } \\
\hline Fratricide: A forensic psychiatric & $\begin{array}{l}\text { Bourget, D. \& Gagne, P. (2006) } \\
\text { Journal of the American Academy of } \\
\end{array}$ & Mental illness and substance abuse impacts fratricidal behavior \\
& $\begin{array}{l}\text { Psychiatry and the Law, 34(4), 529- } \\
533 .\end{array}$ & \\
\hline
\end{tabular}




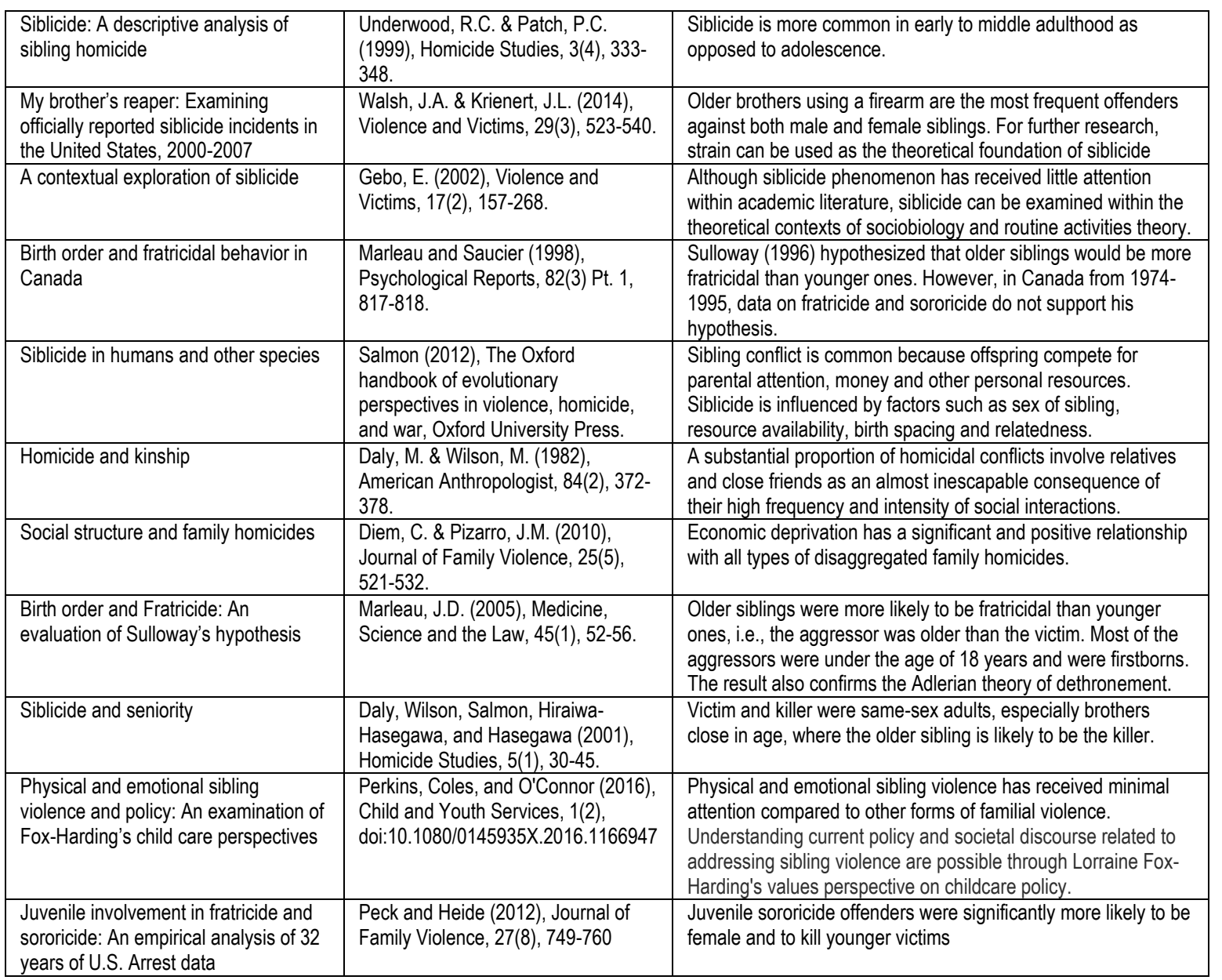

\subsection{Discussions}

This paper examined the elements of family discord through incidences of fratricide and sororicide in Malaysia. The literature search utilized two popular databases, Scopus, and Web of Science. From the keyword searches such as "sibling", "fratricide", "sororicide", "family violence" and "siblicide", the former produced 511 results while the latter produced 330 results. Not all the documents are relevant to the study as the scope included animals and plants. The discussion from the findings will surround three elements of patterns, incidences and, trends and distributions.

There is so specific pattern for siblicide to occur. The environment could trigger the violence, but the age of the perpetrator comes into contention. From Table 2, incidences of fratricide are committed by first-borns under the age of 18. In corroborating this, the killings of the sisters by the respective brothers indicates that boys are prone to homicide than girls.

From the twelve articles listed in Table 2, the incidences of sibling violence and homicide have escalated over the years. Again, looking at Table 1, fratricide (brother kills brother) is a common occurrence. The culmination of the long-standing sibling disputes has ended in death. This points to the overall family relationship from birth to adulthood. As shown from Table 2, the familial violence is reflected from the lack of parenting skills of both the mother and father. If family discord is already internalized when the child begins to understand the environment, then that seed of disharmony has already been sowed. The addition of a younger sibling will result in bullying by the older sibling. Moreover, lack of education and strict tribal culture were also blamed for the increase in family discord, particularly in the rural areas of certain ethnicities.

The pervasive incidences of sibling violence showed significant trends and distributions that need to be addressed such as age, gender, race, offender-victim relationship and geographical distribution. Literature evidenced that these demographic constructs point to psychopathologic tendencies among the siblings that erupted from years of experiencing domestic violence in the family. If no action is taken to overcome this societal and individual psychological ill, it is possible that such cases may increase in number and will continue to contribute to harmful consequences to the family lineage, society and the nation.

\subsection{Conclusion and Recommendation}

As a conclusion, the findings support the increased incidences of fratricide and sororicide, aka, sibling homicide in Malaysia. These incidences bore root in the form of jealousy, which is the primary factor for family discord. Also, male siblings are prone to incidences of fratricide rather than female siblings. The research findings are significant in highlighting the plight of a family's discord which then 
impacts the community as a whole. Other factors that lead to sibling violence and abuse include parent's relationship, financial problems, lack of education, substance abuse and the continuous erosion of civility whether at home or the external environment. It is recommended that further empirical evidence through the deployment of quantitative research design for the triangulation of primary data to corroborate the results from the secondary data analyses. The policy-makers and relevant stakeholders should pay heed to the escalating domestic violence among brothers and sisters and should find ways and means to assist families in need of psychological and behavioral counseling. Better quality of life is expected when such family issues are brought to light.

\section{Acknowledgements}

The research project is funded through the Fundamental Research Grant Scheme (FRGS 34/2015), Ministry of Higher Education, Malaysia. Due acknowledgment is also directed to Universiti Teknologi MARA.

\section{References}

Bourget, D., \& Gagné, P. (2006). Fratricide: A forensic psychiatric perspective. Journal of the American Academy of Psychiatry and the Law, 34(4), 529-533.

Boyse, K. (2012). Sibling Abuse. Health System. Retrieved from Your Child Development \& Behavior Resources: A guide to information and support for parents website: http://www.med.umich.edu/yourchild/topics/sibabuse.htm

Card, D., \& Dahl, G. (2009). Family Violence and Football: The Effect of Unexpected Emotional Cues on Violent Behavior (pp. 15497). Cambridge: National Bureau of Economic Research, Inc.

Chang, Y.-M., \& Luo, Z. (2015). Endogenous division rules as a family constitution: strategic altruistic transfers and sibling competition. Journal of Population Economics, 28(1), 173-194. doi:10.1007/s00148-013-0501-9

D'Amico, R., \& Minenna, C. (2013). Violence between siblings: A neglected issue. Maltrattamento e Abuso all'Infanzia, 15(2), 65-86.

Daly, M., Wilson, M., Salmon, C. A., Hiraiwa-Hasegawa, M., \& Hasegawa, T. (2001). Siblicide and Seniority. Homicide Studies, 5(1), 30-45. doi:10.1177/1088767901005001003

DeKeseredy, W. S., \& Ellis, D. (1997). Sibling Violence: A Review of Canadian Sociological Research and Suggestions for Further Empirical Work. Humanity \& Society, 21(4), 397-411. doi:10.1177/016059769702100405

Eriksen, S., \& Jensen, V. (2006). All in the family? Family environment factors in sibling violence. Journal of Family Violence, 21(8), $497-507$.

Eriksen, S., \& Jensen, V. (2009). A Push or a Punch: Distinguishing the Severity of Sibling Violence. Journal of Interpersonal Violence, 24(1), 183-208. doi:10.1177/0886260508316298

Gebo, E. (2002). A contextual exploration of siblicide. Violence and Victims, 17(2), 157-168.

Hariz, M. (2016, March 23). Brothers' quarrel end in murder. New Straits Times. Retrieved from http://www.nst.com.my/news/2016/03/134479/brothers-quarrel-endsmurder

Hashim, R., \& Ahmad, H. (2016). Family environment, sibling relationship and rivalry towards quality of life. Environment-Behavior Proceedings Journal, 1(3), 113-122.

Huffman, K. L., Jill Kiecolt, K., \& Edwards, J. N. (2005). Physical violence between siblings: A theoretical and empirical analysis. Journal of Family Issues, 26(8), 11031130. doi:10.1177/0192513X05277809

Karlsson, M. E., Temple, J. R., Weston, R., \& Le, V. D. (2016). Witnessing Interparental Violence and Acceptance of Dating Violence as Predictors for Teen Dating Violence Victimization. Violence Against Women, 22(5), 625-646.

doi:10.1177/1077801215605920

Khan, K. S., Kunz, R., Kleijnen, J., \& Antes, G. (2003). Five steps to conducting a systematic review. Journal of the Royal Society of Medicine, 96(3), $118-121$.

Khan, R., \& Cooke, D. J. (2013). Measurement of Sibling Violence: A Two-Factor Model of Severity. Criminal Justice and Behavior, 40(1), 26-39. doi:10.1177/0093854812463349

Kiong, T. C. (2005). Feuds and Legacies: Conflict and Inheritance in Chinese Family Businesses. International Sociology, 20(1), 45-70. doi:10.1177/0268580905049909

Kiselica, M. S., \& Morrill-Richards, M. (2007). Sibling maltreatment: The forgotten abuse. Journal of Counseling and Development, 85(2), 148-160.

Lawson, D. W., \& Mace, R. (2010). Siblings and childhood mental health: Evidence for a later-born advantage. Social Science \& Medicine, 70(12), $2061-2069$. doi:10.1016/j.socscimed.2010.03.009

Lichter, E. L., \& McCloskey, L. A. (2004). The effects of childhood exposure to marital violence on adolescent gender-role beliefs and dating violence. Psychology of Women Quarterly, 28(4), 344-357. doi:10.1111/j.1471-6402.2004.00151.x

Marleau, J. D. (2005). Birth order and fratricide: An evaluation of Sulloway's hypothesis. Medicine Science and the Law, 45(1), 52-56. 
Marleau, J. D., \& Saucier, J. F. (1998). Birth order and fratricidal behavior in Canada. Psychological Reports, 82(3 PART 1), $817-818$.

Nambiar, P. (2016, July 14). Man wanted for killing 4 in family shot dead. Free Malaysia Today. Retrieved from

http://www.freemalaysiatoday.com/category/nation/2016/07/14/man-wanted-for-killing-4-in-family-shot-dead/

Nicholas, C. (2014, October 28). Sister found dead after scolding brother. The Star. Retrieved from http://www.thestar.com.my/news/nation/2014/10/28/sibling-rowends-in-tragedy-sister-found-dead-after-scolding-brother/

Pautasso, M. (2013). Ten Simple Rules for Writing a Literature Review. PLoS Computational Biology, 9(7), e1003149. doi:10.1371/journal.pcbi.1003149

Peck, J. H., \& Heide, K. M. (2012). Juvenile Involvement in Fratricide and Sororicide: An Empirical Analysis of 32 Years of U.S. Arrest Data. Journal of Family Violence 27(8), 749-760. doi:10.1007/s10896-012-9456-y

Perkins, N. H., Coles, D. C., \& O'Connor, M. K. (2016). Physical and emotional sibling violence and policy: An examination of Fox-Harding's child care value perspectives. Child and Youth Services, 1-20. doi:10.1080/0145935X.2016.1166947

Relva, I. C., Alarcão, M., \& Fernandes, O. M. (2014). Rivalry or violence? Perception of university students victims of sibling violence. Psicologia: Teoria e Pesquisa, $30(3), 259-265$

Salmon, C. A. (2012). Siblicide in Humans and Other Species The Oxford Handbook of Evolutionary Perspectives on Violence, Homicide, and War.

Tucker, C. J., \& Finkelhor, D. (2015). The State of Interventions for Sibling Conflict and Aggression: A Systematic Review. Trauma, Violence, \& Abuse. doi:10.1177/1524838015622438

van Beekum, S. (2009). Siblings, Aggression, and Sexuality: Adding the Lateral. Transactional Analysis Journal, 39(2), 129-135. doi:10.1177/036215370903900206

Wallace, A. D. (2015). Family and friendship William Wordsworth in Context (pp. 224-231). 